Al-Huquq: Journal of Indonesian Islamic Economic Law, 2 (2), 2020: 133-159

ISSN: 2715-0003; E-ISSN 2714-5514

DOI: http://dx.doi.org/10.19105/al\%20huquq.v1i1.3161

\title{
Omnibus Law Sebagai Reformasi Hukum Investasi di Indonesia Berdasarkan Asas Hirarki Peraturan Perundang-Undangan
}

\author{
Muhammad Amiril A'la, Aditya Prastian Supriyadi \\ (Alumni Magister Ilmu Hukum Fakultas Hukum Universitas Brawijaya, Jl. \\ Veteran Malang, Ketawanggede, Kecamatan Lowokwaru Kota Malan, 65145)
}

\begin{abstract}
Abstrak:
Tulisan ini bertujuan untuk mendeskripsi, memahami dan menganilisis omnibus law sebagai reformasi hukum investasi di Indonesia berdasarkan asas hirarki peraturan perundangundangan. Adapun dalam penulisan artikel ini menggunakan penelitian hukum normatif. Selain itu penulisan artikel ini menggunakan pendekatan teoritis dan yuridis. Hasil penelitian ini menunjukan bahwa dalam pembentukan omnibus law sebagai aturan yang mempermudah investasi Indonesia akan berlaku asas hirarki peraturan perundang-undngan. Kemudian ada beberapa urgensi pembentukan omnibus law dalam aspek investasi. Salah satunya teori negara kesejahteraan yang berlaku bagi Indonesia menjadi peran untuk meningkat perekonomian di bidang investasi melalui omnibus law dalam rangka mewujudkan amanat konstitusi indonesia yaitu memajukan kesejahteraan umum dan sebesar-besarnya sebagai kemakmuran rakyat Indonesia. (This paper aims to describe, understand and analyze omnibus law as a reform of investment law in Indonesia based on the hierarchical principle of laws and regulations. The writing of this article uses normative legal research. In addition, the writing of this article uses a theoretical and juridical approach. The results of this study indicate that in the formation of the omnibus law as a rule that facilitates Indonesian investment will apply the principle of a legislative hierarchy. Then there is the urgency of establishing an omnibus law in the investment aspect. One of them is the theory of the welfare state that applies to Indonesia as a role to increase the economy in the field of investment through the omnibus law in order to realize the mandate of the Indonesian constitution, namely to promote public welfare as much as possible as the prosperity of the people of Indonesia)
\end{abstract}

email koresproden: amirillazuardi10@gmail.com https://creativecommons.org/licenses/by-nc/4.0/ Copyright (c) 2019 by al-huquq. All Right Reserved 


\section{Kata Kunci:}

Omnibus law, Investasi, Hirarki Peraturan Perundang-Undangan

\section{Pendahuluan}

Negara Indonesia memiliki regulasi yang fundamental tentang aspek pengaturan ekonomi. Hal ini dapat dilihat di dalam pasal 33 ayat 4 Undang-Undang Dasar Negara Republik Indonesia Tahun 1945 (UUD 1945) yang menyebutkan : "Perekonomian nasional diselenggarakan berdasar atas demokrasi ekonomi dengan prinsip kebersamaan, efisiensi berkeadilan, berkelanjutan, berwawasan lingkungan, kemandirian, serta dengan menjaga keseimbangan kemajuan dan kesatuan ekonomi nasional".

Amanat UUD di atas merupakan sebuah kewajiban negara yang wajib mengatur perekonomian dengan beberapa ketentuan yang telah tercantum pada dasar hukum di atas. Semua aspek yang menjadi unsur perekonomian negara dalam UUD wajib dipenuhi dalam rangka mewujudkan sebesar-besarnya kemakmuran rakyat pada aspek kehidupan ekonomi yang berlaku sebagai cita-cita yang perlu diwujudkan¹.

Dalam rangka mewujudkan perekonomian yang menjadi citaciata bangsa maka perlu ada sinergitas antara pemerintah dan investor sebagai aspek kebersamaan². Pemerintah memiliki peran yang sangat besar sebagai regulator perekonomian ${ }^{3}$ yang memudahkan para investor agar para investor tertarik untuk menanamkan modalnya dalam rangka meningkatkan taraf perekonomian yang dapat berdampak baik bagi masyarakat. Sehingga agar sinergitas antara pemerintah dan investor dalam berjalan baik dalam rangka investasi di Indonesia, maka dikeluarkannya beberapa undang-undang perekonomian sebagai pelaksana amanat UUD 1945.

1 Bagir Manan, Pertumbuhan dan Perkembangan Konstitusi Suatu Negara, (Bandung : Mandar Maju), 1995, Hlm. 45

2 Swasosno. Sri Edi, Tentang Demokrasi Ekonomi, (Jakarta : Bappenas), 2008, Hlm. 3

3 D. Soekarno, Amandemen Terhadap UUD 1945, Suara Pembaharuan : http/www. Suarapembaharuan.com, diakses pada tanggal 11 November Tahun 2019 Pukul 21.55 WIB 
Omnibus Law Sebagai Reformasi Hukum Investasi di Indonesia Berdasarkan Asas Hirarki Peraturan Perundang-Undangan

Salah satu undang-undang tentang perekonomian yang berlaku di Indonesia adalah Undang-Undang Nomor 25 Tahun 2007 tentang Penanaman Modal (UU PM). Berlakunya UU PM sebagai kepastian hukum landasan bagi para Investor yang ingin menanamkan modalnya di Indonesia. Dalam UU PM tidak hanya berlaku bagi para investor Indonesia namun juga berlaku bagi investor asing yang tertarik ingin melakukan menamkan modal. Tujuan berlakunya UU PM ini dalam rangka mewujudkan pembangunan ekonomi nasional yang berkadilan dan atas dasar kemakmuran pada rakyat.

Perwujudan perekonomian sesuai amanat UUD 1945 mengalami beberapa kendala yang mengakitban tidak sesuai dengan cita-cita. Kendala tersebut salah satunya berasal dari keberlakuan hukum yang mengatur investasi di Indonesia. Hal ini karena terdapat aturan-aturan investasi yang tumpang tindih dengan aturan lainnya sehingga berdampak pada perizinan investasi yang sulit dan menghilangkan minat investor untuk menanamkan modalnya di Indonesia.

Menanggapi masalah tersebut tentu Presiden Republik Indonesia Ir. H. Joko Widodo tidak tinggal diam. Dalam pidato pertamanya ketika pelantikan jabatan Presiden periode 2 (dua) Joko Widodo memiliki rencana untuk mengatasi permasalahan Investasi melalui Omnibus Law ${ }^{4}$ agar berdampak mempermudah izin investas bagi para Investor yang ingin menanamkan modalnya agar berdampak pada peningkatan pembangunan nasional yang dapat berdampak baik bagi masyarakat.

Omnibus law adalah salah satu kebijakan pengeluaran undangundang yang berdampak pencabutan pada peraturan perundangundangan yang tumpang tindih secara sederhana dan cepat ${ }^{5}$. Ketika Omnibus Law diterapkan dalam bidang investasi, maka akan berlaku suatu aturan yang sederhana tentang investasi dan akan mencabut

4 Kompas, Apa itu Omnibus Law, Yang Disinggung Jokowi dalam Pidatonya? : https://www.kompas.com/tren/read/2019/10/22/070600665/apa-itu-omnibuslaw-yang-disinggung-jokowi-dalam-pidatonya-?page=all, diakses pada tanggal 11 November 2019 Pukul 21.59 WIb

5 Busroh, Firman Freaddy, Konseptualisasi Omnibus Law Dalam Menyelesaikan Permasalahan Regulasi Pertanahan, Jurnal Arena Hukum, Vol. 10, No. 2, Bulan Agustus Tahun 2017, Hlm. 242 
aturan-aturan investasi lainnya yang tidak sesuai dengan berlakunya Omnibus Law tersebut.

Permasalahannya adalah ketika ada isu kebijakan Omnibus Law akan dikeluarkan, muncul pro dan kontra atas isu tersebut. Kebijakan Omnibus Law jika ingin menyederhanakan regulasi investasi dengan mencabut beberapa aturan sebelumnya tentang investasi maka perlu melihat aspek peraturan perundang-undangan agar tetap konstitusional. Kemudian harus benar-benar melihat bahwa Omnibus Law adalah solusi sebagai reformasi hukum investasi yang berdampak pada mekanisme perizinan investasi yang memudahkan bagi para investor untuk menanamkan modalnya sebagai media pembangunan negara dalam aspek perekonomian.

Atas permasalahan yang dijelaskan di atas maka akan ditarik isu hukum yang terdiri 2 (dua) rumusan masalah yaitu : (1) Bagaimana perspektif hukum asas peraturan perundang-undangan pada penerapan omnibus law yang berimplikasi pencabutan beberapa aturan hukum lainnya?, (2) Apa yang menjadi urgensi hukum omnibus law sebagai solusi mempermudah regulasi hukum investasi di Indonesia?

Tujuan penulisan ini adalah untuk mengetahui, memahami dan menganalisis perspektif hukum asas peraturan perundang-undangan pada penerapan omnibus law yang berimplikasi pencabutan beberapa aturan hukum lainnya. Selain itu untuk mengetahui, memahami dan menganalisis urgensi hukum omnibus law sebagai solusi mempermudah regulasi hukum investasi di Indonesia.

Perspektif Hukum Asas Hirarki Peraturan Perundang-Undangan Pada Penerapan Omnibus Law yang Berimplikasi Pencabutan Beberapa Aturan Hukum Lainnya

Negara hukum memiliki beberapa sebutan yang berbedabeda. Ada istilah negara hukum disebut sebagai Rechtststaat yang berasal dari bahasa Belanda. Dalam istilah Inggris yang dikembangkan oleh A.V. Dicey, hal itu dapat dikaitkan dengan prinsip "rule of law" yang berkembang di Amerika Serikat menjadi jargon "the Rule of Law, and not of Man". Yang sesungguhnya dianggap sebagai pemimpin adalah hukum itu sendiri, bukan orang. Dalam buku Plato berjudul "Nomoi" yang kemudian diterjemahkan ke dalam bahasa Inggeris dengan judul "The Laws", jelas tergambar 
Omnibus Law Sebagai Reformasi Hukum Investasi di Indonesia Berdasarkan Asas Hirarki Peraturan Perundang-Undangan

bagaimana ide nomokrasi itu sesungguhnya telah sejak lama dikembangkan dari zaman Yunani Kuno ${ }^{6}$.

Profesor Utrecht membedakan ntara Negara Hukum Formil atau Negara Hukum Klasik, dan Negara Hukum Materiel atau Negara Hukum Modern . Negara Hukum Formil menyangkut pengertian hukum yang bersifat formil dan sempit, yaitu dalam arti peraturan perundang-undangan tertulis. Sedangkan yang kedua, yaitu Negara Hukum Materiel yang lebih mutakhir mencakup pula pengertian keadilan di dalamnya. Karena itu, Wolfgang Friedman dalam bukunya 'Law in a Changing Society' membedakan antara 'rule of law' dalam arti formil yaitu dalam arti 'organized public power', dan 'rule of law' dalam arti materiel yaitu 'the rule of just law'7. Pembedaan ini dimaksudkan untuk menegaskan bahwa dalam konsepsi negara hukum itu, keadilan tidak serta-merta akan terwujud secara substantif, terutama karena pengertian orang mengenai hukum itu sendiri dapat dipengaruhi oleh aliran pengertian hukum formil dan dapat pula dipengaruhi oleh aliran pikiran hukum materiel.

Negara Indonesia memiliki status yang diamanatkan oleh UUD 1945. Adapun status tersebut menjadi identitas negara yaitu negara hukum. Adapun legalitas tersebut terdapat dalam pasal 1 ayat (3) UUD 1945 yang menyebutkan bahwa "Indonesia adalah Negara Hukum". Ketika negara memiliki status sebagai negara hukum maka tentu harus mengedapankan aspek hukum dalam penyelenggaraan pemerintahan baik dibidang apapun terutama bidang perekonomian guna menjadi aturan yang baik dan berdampak pada kemudahan investasi para investor yang akan menanamkan modalnya dalam rangka berpartisipasi atas pembangunan nasional bangsa.

Penyelenggaran negara hukum tentu memiliki konsep dan teori yang perlu diperhatikan. Adapun konsep dan teori tersebut merupakan dasar referensi agar manifetasi negara hukum dalam berjalan baik terutama pada negara Indonesia. Dalam konsep Negara Hukum itu, diidealkan bahwa yang harus dijadikan panglima dalam dinamika kehidupan kenegaraan adalah hukum, bukan politik ataupun ekonomi. Karena itu, jargon yang biasa digunakan dalam

\footnotetext{
6 Plato, The Laws, Penguin Classics, Edisi 1986, translate by Trevor J. Saunders.

7 Utrecht, Pengantar Hukum Administrasi Negara Indonesia, (Jakarta : Ikhtiar), 1962, Hlm. 9
} 
bahasa Inggeris untuk menyebut prinsip Negara Hukum adalah 'the rule of law, not of man'. Yang disebut pemerintahan pada pokoknya adalah hukum sebagai sistem, bukan orang per orang yang hanya bertindak sebagai 'wayang' dari skenario sistem yang mengaturnya8. Artinya walaupun kebijakan hukum dalam aspek ekonomi, aspek tersbuet bukanlah alasan utama sebagai landasan pembuatan hukum tersebut. Melainkan kebijakan hukum ekonomi tersebut sebagai bagian sistem pemberlakuan kepada seluruh masyarakat Indonesia.

Gagasan Negara Hukum itu dibangun dengan mengembangkan perangkat hukum itu sendiri sebagai suatu sistem yang fungsional dan berkeadilan, dikembangkan dengan menata supra struktur dan infra struktur kelembagaan politik, ekonomi dan social yang tertib dan teratur, serta dibina dengan membangun budaya dan kesadaran hukum yang rasional dan impersonal dalam kehidupan bermasyarakat, berbangsa dan bernegara ${ }^{9}$. Dalam mewujudkan kebijakan hukum pada bidang ekonomi maka ada beberapa ketentuan yang dipenuhi. Pertama dari segi aturan kemudian perangkat-perangkat sebagai pelaksana agar tujuan ekonomi yang terdapat pada subtansi kebijakan hukum materil dan mewujudkan amanat ekonomi konstitusi.

Pada konsep negara hukum memiliki ciri-ciri yang menjadi identitas negara tersebut. Beberapa pakar banyak sekali memberikan pandangannya tentang ciri-ciri negara hukum pada teori-teori yang telah dijabarkan. Salah satu pakar yang memberikan pandangan tentang negara hukum adalah Fredish J. Stahl. Adapun menurtunya ciri-ciri dari negara hukum adalah :

1. Adanya pengakuan hak asasi manusia

2. Adanya pembagian kekuasaan

3. Pemerintah berdasarkan peraturan

4. Adanya peradilan tata usaha negara ${ }^{10}$.

8 Jimly Asshidiqie, Gagasan Negara Hukum Indonesia : https://pngunungsitoli.go.id/assets/image/files/Konsep_Negara_Hukum_Indonesia.pdf, diakses pada tanggal 12 November 2019 Pukul 21.13 Wib.

${ }^{9}$ Ibid

10 Oemar Seno Adji, Prasarana Dalam Indonesia Negara Hukum, (Jakarta : Simposium UI), 1966, Hlm. 24 
Omnibus Law Sebagai Reformasi Hukum Investasi di Indonesia Berdasarkan Asas Hirarki Peraturan Perundang-Undangan

Ciri-ciri negara hukum di atas dapat kita lihat salah satunya adalah pemerintahan berdasarkan peraturan. Adapun hal tersebut dikenal istilah Supremacy Of Law atau Supremasi Hukum. Berlakunya supremasi hukum dalam suatu negara maka ini yang menjadi batasan-batasan perbuatan pemerintah. Pemerintah tidak boleh semena-mena untuk bertindak melainkan atas dasar aturan yang berlaku. Hal ini juga tidak lepas ketika pemerintah akan melaksanakan roda perekonomian di Indonesia. Dasar-dasar hukum harus tersedia yang menjadi regulasi ekonomi dan menjadi kepastian hukum yang bermanfaat dan menghindarkan aspek kesewenangan pemerintah ketika akan menjalankan roda perekonomian negara.

Kembali ke supremasi hukum dalam kebijakan perekonomian Indonesia. Semua hal aspek ekonomi dari negara harus ada kepastian hukum yang tersedia dan berlaku. Mulai aturan yang paling tinggi dan aturan yang berada di ranah bawah dibuat sebagai bentuk supremasi hukum negara dalam menjalankan roda perekonomian negara. Dalam aturan tersebut ada tata aturan dan teori yang perlu diikuti agar pembentukan peraturan sesuai dengan kaidah tanpa ada kepentingan dari siapapun. Misalnya ketika berbicara ekonomi dalam aspek hukum, maka harus melihat dasar hukum secara fundamemtal dari UUD 1945. Kemudian segala peraturan dibawahnya dibuat sebagai teknis pelaksanaan perwujudan amanat UUD dan tentunya aturan-aturan yang berada diranah posisi paling bawah tidak boleh bertentangan dengan aturan yang diatas. Artinya ada sinergitas dan korelasi yang baik antara peraturan perundang-undangan tanpa ada tumpang tindih yang dapat berdampak buruk pada kekaburan hukum karena aturan hukum formal yang memiliki perbedaan amanat dan melenceng dari amanat aturan dasar. Jika hal tersebut terjadi pada ranah kebijakan ekonomi maka dapat berpotensi menurunya tingkat perekonomian karena dasar hukum yang berlaku memiliki kualitas buruk. Sehingga perlu ada sebuah sinergi yang baik antara aturan yang berada diatas tetap menjadi pedoman aturanaturan yang ada di bawahnya dalam rangka mewujudkan ekonomi yang baik di Negara Indonesia.

Beberapa aturan-aturan yang berlaku dan menjadi produk Negara hukum tentu sangat berkaitan dengan pembentukan peraturan perundang-undangan. Pembentukan peraturan perundang-undangan merupakan suatu sistematis terkait dasar-dasar 
dan teknis suatu pembentukan aturan yang tepat terutama sejalur dengan hirarkis peraturan perundang-undangan. Hal tersebut perlu dilakukan agar tidak terjadi pertentangan dengan peraturan yang lainnya.

Di Negara Indonesia pembentukan peraturan perundangundangan telah di atur dalam UU. No 12 Tahun 2011. Di dalam pasal 7 ayat (1) telah tertera hirarkis peraturan perundang-undangan yang berlaku di Indonesia. Adapun peraturan tersebut terdiri dari :

1. Undang-Undang Dasar Negara Republik Indonesia Tahun 1945

2. Ketetapan Majelis Permusyawaratan Rakyat Indonesia

3. Undang-Undang Negara Republik Indonesia/ Peraturan Pengganti Undang-Undang

4. Peraturan Pemerintah

5. Peraturan Presiden

6. Peraturan Daerah Provinsi

7. Peraturan Daerah Kab./ Kota.

Hirarkis peraturan di atas adalah suatu tingkatan yang berlaku di Indonesia. Semua aturan diatas harus bersinergi dan memiliki harmonisasi antar keberlakuan agar tidak terjadi pertentangan yang mengakibatkan tumpang tindihnya aturan. Jika itu terjadi maka suatu hal yang perlu dikoreksi terutama pada sistematis mekanisme pembentukan peraturan perundang-undangan apakah sudah sesuai atau belum.

Maria Farida Indrati Soeprapto menyatakan bahwa istilah perundang- undangan (legislation, wetgeving, atau gezetzgebbung) mempunyai dua pengertian ${ }^{11}$ :

1. Perundang - Undangan merupakan proses pembentukan/ proses membentuk peraturan - peraturan Negara, baik tingkat pusat maupun ditingkat daerah.

2. Perundang -undangan adalah segala peraturan Negara, yang merupakan hasil pembentukan peraturan - peraturan, baik ditingkat pusat maupun di tingkat daerah.

11 Mahendra Kurniawan, Dkk, Pedoman Naskah Akademik PERDA Partisipatif, (Yogyakarta : Kreasi Total Media), 2007, Hlm. 5 
Omnibus Law Sebagai Reformasi Hukum Investasi di Indonesia Berdasarkan Asas Hirarki Peraturan Perundang-Undangan

Produk hukum yang masuk kategori hirarkis peraturan perundang-undangan dikeluarkan oleh institusi baik yang berada ditingkat pusat maupun daerah. UUD 1945 s/d Peraturan Presiden adalah hasil produk hukum institusi pusat. Kemudian Peraturan Daerah baik d tingkat provinsi maupun kab./ kota adalah produk hukum institusi tingkat daerah.

Dalam pembentukan peraturan terdapat asas-asas yang berlaku dalam hirarkis peraturan perundang-undangan. Adapun asas tersebut akan dijelaskan dibawah ini :

1. Undang-undang yang lebih tinggi mengesampingkan undang-undang yang lebih rendah (lex superiori derogate lex inferiori). Menurut asas ini bahwa peraturan perundangundangan yang lebih rendah tingkatannya tidak boleh bertentangan dengan peraturan perundangundangan yang lebih tinggi dalam mengatur hal yang sama. Konsekuensi hukum asas lex superiori derogate lex inferiori ialah: a) undang-undang yang dibuat oleh penguasa yang lebih tinggi mempunyai kedudukan yang lebih tinggi pula; b) undang-undang yang lebih rendah tidak boleh bertentangan dengan undang-undang yang lebih tinggi ${ }^{12}, \mathrm{c}$ ) perundangundangan hanya dapat dicabut, diubah, atau ditambah oleh atau dengan peraturan perundangundangan yang sederajat atau yang lebih tinggi tingkatannya. Tidak ditaatinya asas tersebut akan dapat menimbulkan ketidak-tertiban dan ketidakpastian dari sistem perundang-undangan. Bahkan dapat menimbulkan kekacauan atau kesimpangsiuran perundangundangan.

2. Undang-undang yang bersifat khusus mengesampingkan undang-undang yang bersifat umum (lex specialis derogate lex generalis). Menurut asas ini apabila ada dua macam ketentuan peraturan perundangan yang setingkat atau kedudukannya sama dan berlaku dalam waktu yang bersamaan serta saling bertentangan, maka hakim harus

12 Sugiarto, Umar Said, Pengantar Hukum Indonesia, (Jakarta : Sinar Grafika), 2013, Hlm. 62 
menerapkan atau menggunakan yang khusus sebagai dasar hukum, dan mengesampingkan yang umum ${ }^{13}$.

3. Undang-Undang yang berlaku belakangan membatalkan undang-undang terdahulu (lex posteriori derogate lex priori). Maksudnya adalah undang-undang atau peraturan yang terdahulu (lama) menjadi tidak berlaku apabila penguasa yang berwenang memberlakukan undangundang atau peraturan yang baru dalam hal mengatur objek yang sama, dan kedudukan undang-undang atau peraturannya sederajat.

Dalam penyelenggaraan Negara hukum pada bidang perekonomian, maka perlu dasar-dasar aturan sebagai landasan kepastian hukum untuk kebijakan. Aspek hukum kebijakan perekonomian Negara tentu melalui produk hukum baik tingkat pusat maupun daerah. Mulai dari hirarkis UUD s/d Perda terkait berlaku kebijakan ekonomi baik tingkat pusat maupun daerah. Segala aturan kebijakan perekonomian mulai dari UUD s/d perda perlu ada harmonisasi. Artinya keselarasan amanat aturan yang tidak boleh bertentangan agar sinergitas aturan dapat berjalan baik dan dijauhkan dari kepentingan tertentu karena sejatinya aturan itu dikeluarkan sebagai sebesar-besarnya kepentingan rakyat dalam aspek perekonomian.

Pelaksanaan pembangunan perekonomian di Indonesia memiliki banyak permasalahan yang perlu ada solusi agar bisa berjalan dengan sesuai dengan amanat tujuan konsitusi ekonomi. Beberapa masalah terdapat dari beberapa aspek yang salah satunya aspek hukum. Saat ini isu yang sedang menjadi perbincangan adalah bahwa Negara Indonesia mempunyai produk hukum yang sangat berlebihan atau dikenal dengan Hybrid Law. Jumlah hukum yang terlalu banyak tentu berdampak pada pemberlakuan yang tidak efektif dan efisien karena terlalu banyak ketentuan-ketentuan. Hal ini dalam aspek ekonomi tentu akan sangat menjadi masalah karena dapat menghambat kebijakan ekonomi tertutama sulitnya investor yang akan menanamkan modalnya karena terhambat banyak aturanya yang berlaku. Dan karenanya jumlahya yang terlalu banyak,

13 Ibid, Hlm. 64 
Omnibus Law Sebagai Reformasi Hukum Investasi di Indonesia Berdasarkan Asas Hirarki Peraturan Perundang-Undangan

potensi tumpang tindih peraturan juga terjadi karena faktor setiap perbedaan institusi yang memiliki kewenangan namun berbeda arah dan wilayah.

Menyikapi permasalahan tersebut tersebut Presiden Joko Widodo sedang menyiapkan strategi untuk menyelesaikan permasalahan yang menghambat jalannya perekonomian dalam aspek hukum. Maka pada saat pidato kenegaraan presiden ketika pelantikan periode 2 masa jabatannya, Joko Widodo ingin mewujudkan komitmennya dalam membuka keran investasi yang lebih mudah tanpa ada kendala yang dapat menarik minat investor. Maka kedepannya akan dikeluarkannya suatu kebijakan aturan yang disebut dengan Omnibus Law. Adapun produk hukum tersebut akan menjadi pilar utama pada landasan regulasi investasi yang tidak menyulitkan dan bisa berjalan dengan efektif terutama pada mekanisme perizinan bagi para investor yang akan masuk ke Indonesia.

Pembuatan Omnibus Law rencananya akan dibuat dalam ranah undang-undang. Maka tentu pembuatan regulasi tersebut kewenangan dari Dewan Perwakilan Rakyat. Namun tetap perlu ada kontribusi dari presiden karena usulan regulasi tersebut berasal dari pihak presiden. Artinya perlu ada hubungan yang baik sinergitas politik yang membangun agar pembuatan omnibus law ini menjadi 1 (satu) visi dalam rangka kebaikan perekonomian kedepannya.

Teknis pelaksanaan omnibus law ini akan menjadi penyederhanaan aturan yang sudah cukup banyak di Indonesia baik ditingkat pusat atau daerah. Jika Omnibus Law ini berlaku akan berimplikasi pada aturan lainnya terutama aturan di sektor ekonomi. Adapun implikasi hukum nya adalah akan membatalkan aturanaturan yang tidak sesuai dengan subtansi dari Omnibus Law yang akan berlaku. Yaitu keberlakuan hukum terkait investasi pada sektor perekonomian hanya akan berlaku Omnibus law saja sebagai bentuk kesederhanaan peraturan yang dapat mengudang para investor baik investor dalam negeri dan investor asing.

Namun dalam isu pembuatan regulasi omnibus law ini tentu menjadi isu hanya perbincangan di Indonesia. Banyak nya spekulasi respon baik pro dan kontra merupakan pengaruh atas keberlakuan sistem demokrasi indonesia yang memiliki ruang untuk berpendapat secara lisan maupun pemikiran. Hal tersebut tentu menjadi iklim 
demokrasi yang baik dalam rangka menyerap aspirasi masyarakat. Tentunya pro terhadap pembuatan omnibus law menjadi support moral dalam mewujudkannya. Akan tetapi pendapat kontra dari para pihak lain juga belum tentu sebagai landasan bukan sebagai pembentukan aturan tersebut. Melainkan menjadi referensi dalam pembuatan untuk mencari kekurangan agar bisa menjadi aturan yang baik terutama baik bagi perekonomian di Indonesia.

Pembentukan omnibus law agar tidak terjadi kontroversi di masyarakat perlu dibuat secara maksimal terutama berdasarkan pembentukan peraturan perundang-undangan baik dalam segi aspek teori hukum maupun dogmatik hukum. Dalam UU No. 12 Tahun 11 Tentang Pembentukan Peraturan Perundang-Undangan dijelaskan bahwa sumber utama hukum di Indonesia adalah Pancasila. Maka walaupun Omnibus Law dibuat dalam rangka melonggarkan perizinan investasi yang lebih mudah harus tetap mengikuti ideologi Pancasila. Ideologi ini yang menjadi aspek teoritis, filosofis, sosilogis dll. Dalam pembentukan aturan terutama agar tetap menjamin hakhak masyarakat tanpa berpihak pada kepentingan tertentu.

Kemudian segala teori pembentukan teori peraturan perundang-undangan harus menjadi pedoman. Seperti hal nya asasasas peraturan perundangan dalam aspek hirarkis aturan. Karena implikasi Omnibus Law adalah penyederhanaan maka sangat identik dengan keberlakuan asas-asas hirarkis peraturan perundangundangan. Tentu hal tersebut harus benar-benar dibuat dengan benar karena implikasi pencabutan peraturan sangat banyak tetapi tetap konstitusional dan tidak melanggar kaidah teoritik, nomatif dan filosofi hukum.

Ketika berbicara asas hirarki peraturan perundang-undangan maka tidak lepas dari beberapa asas yang telah disinggung sebelumnya. Adapun beberapa asas yang akan berlaku tersebut adalah :

1. Peraturan yang lebih tinggi akan mengenyampingkan peraturan yang lebih rendah (Lex Superiori derograt legi priori). Omnibus Law akan berlaku asas tersebut jika ada peraturan pemerintah $\mathrm{s} / \mathrm{d}$ peraturan daerah tidak sesuai dengan amanat hukum tersebut. Artinya Omnibus Law sebagai undang-undang yang memiliki kedudukan lebih tinggi daripada aturan dibawahya. Sehingga aturan segala 
Omnibus Law Sebagai Reformasi Hukum Investasi di Indonesia Berdasarkan Asas Hirarki Peraturan Perundang-Undangan

peraturan-peraturan yang ada dibawah undang-undang harus menyesuaikan dengan aturan yang di atasnya. Jika aturan dibawah nya tidak sesuai dengan amanat aturan diatasnya maka aturan tersebut tidak berlaku karena bertentangan. Asas tersebut yang menjabarkan mengapa Omnibus Law akan mencabut aturan-aturan dibawahnya. Terutama dalam hal perekonomian pada bidang investasi. Omnibus law akan memiliki subtansi yang mempermudah investasi. Namun apabila aturan teknis dibawahnya dirasa masih memiliki unsur yang menyulitkan invetasi makan aturan tersebut tidak akan berlaku.

2. Peraturan yang baru akan mengenyampingkan peraturan yang lebih lama (Lex Post Teriori Derograt Legi Apriori). Pada asas ini memiliki perbedaan dengan asas peraturan yang lebih khusus akan mengenyampingkan aturan yang lebih umum. Omnibus Law adalah aturan yang bersifat umum karena merupakan aturan gabungan perekonomian. Tentu prioritas undang-undang ini tidak akan berlaku jika menggunakan asas tersebut. Karena aturan ekonomi sudah ada yang lebih khusus. Misalnya UU. No. 25 Tahun 2007 tentang Penanam Modal, UU No 20 Tahun 2008 tentang UMKM. Biasanya penggunaan asas ini jika sejak awal sudah aturan umum, namun dalam perjalannya ternyata ada kebutuhan pengaturan dari subtansi aturan umum yang hanya berlaku pada kalangan tertentu maka dibuatnya UU yang bersifat lebih khusus. Misalnya UU. No. 8 Tahun 1981 tentang Kitab Undang-Undang Hukum Acara Pidana. Namun aturan tersebut kurang tepat jika diterapkan kepada anak. Maka hadirnya aturan UU. No. 11 tahun 2012 tentang Sistem Peradilan Pidana anak yang berlaku bagi hukum acara pidana anak.

Maka asas yang tepat digunakan pada Omnibus law yang dapat mengenyampingkan aturan setingkat UU adalah dengan asas peraturan yang baru mengenyampingkan aturan yang lama. Asas ini juga berlaku pada UU. No 23 Tahun 2014 tentang Pemerintahan Daerah. Adapun berlakunya asas tersebut pada aturan itu adalah dimana UU Pemda mencabut kewenangan walikota dan bupati untuk 
memberikan izin usaha pertambangan (IUP) yang diatur pada aturan yang lebih khusus di UU. No. 4 Tahun 2009 tentang Pertambangan Mineral dan Batu-Bara. Asas tersebut dapat dilihat dari aturan peralihan yang tegas menyatakan terdapat pencabutan kewenangan IUP oleh walikota atau bupati. Hal ini yang menjadi perbedaan dengan asas peraturan khusus mengenyampingkan aturan umum dimana asas ini tidak perlu ada keterangan tegas pada pergantian aturan karena akan segera secara automatis berlaku sedangkan asas peraturan baru akan mengenyampingkan aturan lama butuh penegasan dari atura tentang pergantian tersebut.

Sehingga jika ingin mencabut peraturan ekonomi pada tingkat undang-undang yang dirasa tidak sesuai dengan kebutuhan maka asas peraturan yang baru mengenyampingkan aturan yang lebih lama. Akan tetai di ketentuan peralihan perlu ada penegasan amanat pasal dan ayat aturan yang menyatakan seruan pergantian aturan tertentu. Maka inilah dasar penjelasan mengapa secara asas hirarkis peraturan perundang-undangan Omnibus Law secara konstitusinal dapat diterapkan dan dalam rangka peningkatan ekonomi ini adalah upaya efisiensi dalam rangka peningkatakan ekonomi melalui aturan baru yang mempermudah perizinan pada regulasi Ekonomi.

\section{Urgensi Hukum Omnibus Law Sebagai Solusi Mempermudah Regulasi Hukum Investasi di Indonesia}

Presiden Joko Widodo menyampaikan bahwa dalam periode ke- 2 (dua) pada masa jabatan presidennya ini akan melakukan upaya reformasi perekonomian di Indonesia. Beberapa langkah akan dilakukan dari aspek hukum. Yaitu reformasi perubahan aturan perekonomian melalui Omnibus Law. Hal ini dilakukan karena Presiden RI ingin regulasi investasi negara Indonesia dipermudah dengan cara mempermudah izin agar para investor tertarik untuk menanamkan modalnya di Indonesia.

Banyak sekali manfaat dalam membuka keran investasi di Negara Indonesia. Hal yang paling utama adalah dengan negara Indonesia tidak bisa membangun negara dengan sendiri akan tetapi dibutuhkan para investor untuk turur serta dalam membangun roda perekonomian agar berdampak pada peningkatan kualitas ekonomi. Tentunya hal sebagai dasar mewujudkan kemakmuran rakyat dan kesejahteraan umum seperti pembukaan lapangan kerja, 
Omnibus Law Sebagai Reformasi Hukum Investasi di Indonesia Berdasarkan Asas Hirarki Peraturan Perundang-Undangan

meningkatkan kualitas ekonomi rakyat dan bagi pemasukan oleh negara sebagai income pembangunan selanjutnya baik pembangunan infrastruktur, pembangunan ekonomi dan pembanguna kemanusiaan yang lebih baik.

Dalam mewujudkan ketentuan di atas maka perlu aspekaspek tertntuk untuk menunjang perwujudan yang bisa terjadi. Salah satunya melalui aspek hukum. Karena Indonesia adalah negara hukum maka perlu dasar hukum yang baik dan mempermudah bagi para investor akan tetapi tidak merugikan negara dan masyarakat. Karena posisinya adalah negara Indonesia membutuhkan kehadiran investor bukan atas dasar komersil saja. Namun lebih pada kerja sama dalam pembangunan yang sama-sama menguntungkan antara negara dan investor (feedback). Jika aturan hukum tidak baik dalam perizinan investasi maka tentu para investor akan membelokkan arah investasi ke negara lainnya.

Tugas negara Indonesia dalam mewujudkan kesejahtreaan dan kemakmuran rakyat yang menjadi cita-cita UUD 1945 tidak lepas dengan kedudukan negara hukum yang bersifat modern. Negara hukum yang bersifat klasik hanya berfokus pada negara saja. Akan tetapi negara hukum modern tidak hanya berfokus pada negara namun juga berfokus pada kesejahteraan rakyat di dalamnya. Negara hukum modern tersebut lebih pada konsep negara kesejahteraan dalam rangka mendorong kualitas negara dengan memberdayakan masyarakat di negara tersebut. ${ }^{14} \mathrm{Hal}$ ini yang sedang ditempuh di Indonesia. Berbagai kebijakan dan aturan dikeluarkan untuk masyarakat dari mulai bidang pendidikan, kebudayaan, ekonomi dan lain-lain.

Besarnya perhatian atas isu negara kesejahteraan (welfare state), mengingat bahwa negara kesejahteraan (welfare state) dianggap sebagai jawaban yang paling tepat atas bentuk keterlibatan negara dalam memajukan kesejahteraan rakyat Membangun negara kesejahteraan, menjadi obsesi banyak negara baru terutama di Asia yang merdeka setelah Perang Dunia II. Beberapa negara seperti Korea Selatan, Taiwan, dan Singapura merupakan

14 Bisariyadi, Pergulatan Paham Negara Kesejahteraan (Welfare State) dan Negara Regulasi (Regulatory State) dalam Perkara Konstitusional, Jurnal Hukum Ius Quia Iustum, Vol. 23, No. 4 , Bulan Oktober 2016, Hlm. 532 
negara-negara yang cukup berhasil membangun negara kesejahteraan.

Demikian pula, negara kesatuan republik Indonesia, sebagaimana diamanatkan dalam UUD 1945. Didesain sebagai negara kesejahteraan (welfare state). Menurut Pierson kata kesejahteraan (welfare) di dalamnya paling tidak mengandung tiga subklasifikasi,yakni: (1) Social welfare, yang mengacu kepada penerimaan kolektif kesejahteraan; (2) Economic welfare, yang mengacu kepada jaminan keamanan melalui pasar atau ekonomiformal; dan (3) State welfare, yang mengacu kepada jaminan pelayanan kesejahteraan sosial melalui agen dari negara. Negara Kesejahteraan (welfare state) secara singkat didefinisikan sebagai suatu negara dimana pemerintahan negara dianggap bertanggung jawab dalam menjamin standar kesejahteraan hidup minimum bagi setiap warga negaranya ${ }^{15}$.

Indonesia sebagai negara yang sedang memikul beban negara kesejahteraan maka perlu memiliki inovasi dan kebijakan yang baik dibidang ekonomi. Pengeluaran omnibus law dalam bidang ekonomi diharapkan dapat berdampak pada tujuan negara kesejahteraan yang kemudian berpengaruh dalam minat investor di Indonesia. Tentu jika minal investor di Indonesia sangat tinggi, maka dapat berdampak pada penerimaan negara dari investasi ini. Akan tetapi dalam mewujudkan minat investor yang tinggi perlu ada jaminan ekonomi dalam segi keamanan agar roda perekonomian berjalan baik pada investor. Jika hal tersebut berjalan dengan baik maka tentu dapat meningkatkan perekonomian untuk melaksanaan tugas negara kesejahteraan kepada warga-warganya atas hasil aktivitas dari segi investor di Indonesia.

Dalam perspektif hukum, Wilhelm Lunstedt berpendapat: law is nothing but the very life of mindkind in organized groups and the condition which make possible peaceful co-existence of masses of individuals and social groups and the coorporation for other ends than more existence and propagation.

Dalam pemahaman ini, Wilhelm Lunstedt nampak menggambarkan bahwa untuk mencapai Social Welfare, yang pertama

15 Oman Sukmana, Konsep dan Desain Negara Kesejahteraan (Welfare State), Jurnal Sospol, Vol. 2 No. 1 (Juli-Desember 2016), Hlm. 104 
Omnibus Law Sebagai Reformasi Hukum Investasi di Indonesia Berdasarkan Asas Hirarki Peraturan Perundang-Undangan

harus diketahui adalah apa yang mendorong masyarakat yang hidup dalam satu tingkatan peradaban tertentu untuk mencapai tujuan mereka. Pendapat Lunsteds mengenai social welfare ini hampir sama dengan pendapat Roscou Pound, namun demikian ia ingin menegaskan bahwa secara faktual keinginan sebagian besarmanusia yaitu ingin hidup dan mengembangkannya secara layak.

Melihat pandangan mengenai social welfare tersebut, dapat ditarik kesimpulan bahwa bidang social welfare mencakup semangat umum untuk berusaha dengan dalil-dalilnya dan adanya jaminan keamanan, sehingga dapat dibuktikan bahwa ketertiban hukum harus didasarkan pada suatu skala nilai nilai tertentu, yang tidak dirumuskan dengan rumus-rumus yang mutlak akan tetapi dengan memperhatikan kepentingan-kepentingan masyarakat yang berubahubah mengikuti perubahan zaman, keadaan, dan perubahan keyakinan bangsa ${ }^{16}$.

Kunci pokok dalam negara kesejahteraan adalah isu mengenaijaminan kesejahteraan rakyat oleh negara. Mengenai halini, Jurgen Habermas berpendapat bahwa jaminan kesejahteraan seluruh rakyat merupakan hal pokok bagi negara modern. Selanjutnya menurut Habermas, jaminan kesejahteraan seluruh rakyat yang dimaksud diwujudkan dalam perlindungan atas The risk of unemployment, accident, ilness, old age, and death of the breadwinner must be covered largely through welfare provisions of the state ${ }^{17}$.

Dengan demikian, dalam hakekatnya negara kesejahteraan dapat digambarkan keberadaannya sebagai pengaruh dari hasrat manusia yang mengharapkan terjaminnya rasa aman, ketentraman, dan kesejahteraan agar tidak jatuh ke dalam kesengsaraan. Alasan tersebut dapat digambarkan sebagai motor penggerak sekaligus tujuan bagi manusia untuk senantiasa mengupayakan berbagai cara demi mencapai kesejahteraandalam kehidupannya. Sehingga ketika keinginan tersebut telah dijamin dalam konstitusi suatu negara, maka keinginan tersebut harus dijamin dan negara wajib mewujudkan keinginan tersebut. Dalam konteks ini, negara ada dalam tahapan sebagai negara kesejahteraan.

\footnotetext{
16 Soemardi, Teori Hukum dan Negara : Dasar-Dasar Ilmu Hukum Normatif Sebagai Ilmu Hukum Deskriptid - empirik, (Bandung : Bee Media Indonesia, hlm. 225

17 Gianfranco Poggi, The Development Of The Modern State "Sosiological Introduction, (California : Stanford Uiversity press), 1992, Hlm. 126
} 
Negara Kesatuan Republik Indonesia juga menganut faham Negara Kesejahteraan. Hal ini ditegaskan oleh para Perintis Kemerdekaan dan para Pendiri Negara Kesatuan Republik Indonesia bahwa negara demokratis yang akan didirikan adalah "Negara Kesejahteraan" (walvaarstaat) bukan "Negara Penjaga Malam" (nachtwachterstaat). Dalam pilihan terkait konsepsi negara kesejahteraan Indonesia ini, Moh. Hatta menggunakan istilah "Negara Pengurus"18. Prinsip Welfare State dalam UUD 1945 dapat ditemukan rinciannya dalam beberapa pasal, terutama yang berkaitan dengan aspek social ekonomi.

Dengan masuknya perihal kesejahteraan dalam Undang Undang Dasar Negara Republik Indonesia Tahun 1945, menurut Jimly Asshidiqie Konstitusi Indonesia dapat disebut sebagai konstitusi ekonomi (economic constitution) dan bahkan konstitusi sosial (social constitution) sebagaimana juga terlihat dalam konstitusi Negara Rusia, Bulgaria, Cekoslowakia, Albania, Italia, Belarusia, Iran, Suriah dan Hongaria. Selanjutnya menurut Jimly, sejauh menyangkut corak muatan yang diatur dalam UUD 1945, nampak dipengaruhi oleh corak penulisan konstitusi yang lazim ditemui pada Negaranegara sosialis ${ }^{19}$.

Kewajiban, tujuan dan tugas negara sebagai negara kesejahteraan tentu sangat besar sekali. Hal utama bagi negara kesejahteraan adalah bagaimana untuk memberikan kesejahteraan kepada warganya. Tentu segala cara akan dilakukan agar warga negara tetap bisa hidup berkembang dengan baik. Maka negara harus bisa memaksimal potensinya baik memaksilkan potensi dalam negeri dan juga dapat meningkatkan nilai ekonomi dalam aspek-aspek tertentu terutama dalam rangka memberikan tawaran kepada para investor untuk menanmkan modalnya agar bisa berpengaruh pada peningkatan roda perekonomian Indonesia.

Maka sekali lagi dalam negara hukum adalah kebijakan hukum yang diperhatikan. Saat ini hukum investasi Indonesia masih terkendala dalam teknis perizinan oleh investor karena memiliki

18 M. Yamin, Naskah Persiapan UU 1945 : Risalah Sidang BPUPKI/ PPKI, (Jakarta : Sekretariat Jendral RI), 1959, Hlm. 299

19 Jimly Asshiddiqie, Hukum Tata Negara dan Pilar-Pilar Demokrasi, (Jakarta : Konstitusi Press), 2004, Hlm. 124 
Omnibus Law Sebagai Reformasi Hukum Investasi di Indonesia Berdasarkan Asas Hirarki Peraturan Perundang-Undangan

waktu yang lama. Tentu hal tersebut perlu segera di atasi. Munculny gagasan omnibus law bisa jadi menjadi solusi agar regulasi investasi kita berjalan dengan baik dan sesuai dengan tujuan hukum agar perekonomian negara Indonesia memiliki kepastian hukum, kebermanfaatan hukum dan keadilan hukum.

Gustav Radbruch yang mengemukakan bahwa hukum dalam tujuannya perlu berorientasi pada tiga hal, 1). Kepastian hukum, 2).Keadilan, 3). Daya-guna (kebermanfaatan) (doelmatigheid) ${ }^{20}$.

\section{Kepastian Hukum}

Hukum harus memiliki kepastian, untuk itu maka hukum harus berupa peraturan tertulis. Akan tetapi sangat penting untuk dipahami bahwa Undang-undang tidak dapat menguras hukum ${ }^{21}$. Karena meskipun aturan hukum dirumuskan dalam teks-teks hukum, kata-kata dalam teks tersebut tidak dapat memperhitungkan sepenuhnya isi dan tujuan dari aturan hukum tersebut ${ }^{22}$. Makin banyak hukum memenuhi syarat "peraturan yang tepat", yang sebanyak mungkin menghilangkan unsur ketidakpastian, jadi makin tepat dan tajam peraturan hukum itu, makin terdesaklah keadilan. Itulah arti summum ius, summa iniura ${ }^{23}$, atau lebih sering kita dengar dengan ungkapan Keadilan tertinggi adalah ketidakadilan yang tertinggi ${ }^{24}$.

Pembuatan omnibus law ke dalam teks undang-undang merupakan suatu bentuk kepastian hukum. Karena dirumuskan dalam undang-undang maka tentu perlu isi aturan yang tegas. Sangat hindarkan esensi hukum yang bertentangan satu sama lainnya. Serta menghindari isi yang multi tafsir. Namun yang paling penting adalah terdapat ruang bagi para investor untuk memudahkan investasinya

20 O. Notohamidjojo, Soal-Soal Pokok Filsafat Hukum, (Griya Media : Salatiga, 2011), Hlm. 33

21 Mertokusumo Sudikno \& Pilto, Bab-Bab Penemuan Hukum, (Citra Aditya Bakti : Bandung), Hlm. 53

22 Priyanto, Kuat Puji, Pengantar Ilmu Hukum (Kesenian Hukum dan Penemuan Hukum dalam Konteks Hukum Nasional), (Yogyakarta : Kanwa Publisher, 2011), Hlm. 2

${ }_{23}$ Van Apeldorn, Pengantar Ilmu Hukum (Cet. 32), (Pradya Paramitha : Jakarta, 2000), Hlm. 13

${ }^{24}$ Marzuki, Peter Mahmud, Op.Cit, Hlm. 139 
dengan perizinan yang cepat dan sederhana melalui omnibus law.

\section{Kemanfaatan Hukum (utilititarianisme)}

Pendapat berikutnya mengutarakan bahwa tujuan hukum adalah kemanfaatan. Bahwa hukum harus ditujuakan untuk sesuatu yang berfadah atau memiliki manfaat. Penganut aliran utilitis yang dipelopori oleh Jeremi Bentham mengatakan bahwa hukum bertujuan untuk memastikan kebahagiaan sebesar mungkin bagi manusia dalam kondisi terbaik (the greatest good of the greatest number) yang intinya esensi teori utility bertujuan untuk menghasilkan kesenangan atau kebahagiaan terbesar bagi jumlah terbanyak ${ }^{25}$.

Bentham menerapkan salah satu prinsip dari aliran utilititarianisme ke dalam lingkungan hukum, yaitu manusia akan bertindak untuk mendapatkan "kebahagiaan" sebesarbesarnya dan mengurani penderitaan. Ukuran baik buruknya suatu perbuatan manusia tergantung kepada apakah perbuatan itu mendatangkan kebahagiaan atau tidak. Begitu juga dengan pembentuk undang-undang yang dapat mencerminkan keadilan bagi semua individu. Dengan berpegang pada prinsip tersebut di atas, perundang-undang itu hendaknya dapat memberikan kebahagiaan yang terbesar bagi sebagian besar masyarakat ${ }^{26}$. Kemudian bentham menambahkan tugas hukum adalah memeliharaan kebaikan dan mencegah kejahatan. Tegasnya memilikihara kegunaan ${ }^{27}$.

Pandangan Bentham sebenarnya beranjak dari perhatiannya yang besar terhadap individu. Ia menginginkan agar hukum pertama-pertama dapat memberikan jaminan kebahagiaan kepada individu, bukan langsung ke masyarakat langsung secara keseluruhan. Bentham tidak menyangkal, bahwa disamping kepentingan individu, kepentingan masyarakatpun perlu diperhatikan. Agar tidak terjadi

25 Mertokusumo Sudikno, Mengenal Hukum : Sebuah Pengantar, (Liberty : Yogyakarta, 2008), Hlm. 80

26 Rasjidi Lili \& Rasjidi, Ira Thania, Pengantar Filsafat Hukum, (Bandung : Mandar Maju, 2002), Hlm. 60

27 Modiharjo, Darji Dar \& Shidarta Arif, Pokok-Pokok Filsafat Hukum, (Jakarta : Gramedia, 2006), Hlm. 118 
Omnibus Law Sebagai Reformasi Hukum Investasi di Indonesia Berdasarkan Asas Hirarki Peraturan Perundang-Undangan

bentrokan, kepentingan individu dalam mengejar kebahagiaan sebesar-besarnya itu perlu dibatasi. Jika tidak, akan terjadi apa yang disebut homo homini lupus (manusia menjadi serigala bagi manusia lainnya). Untuk menyeimbangkan antar kepentingan (individu dan masyarakat), bentham menyarankan agar ada simpati dari tiap-tiap individu. Walaupun demikian, titik berat perhatian harus tetap pada individu, karena apabila setiap individu telah memperoleh kebahagiaanya, dengan sendirinya kebahagiaan (kesejahteraan) masyarakat akan dapat diwujudkan secara simultan ${ }^{28}$.

Teori utilititarianisme menekankan pentingnya akibat baik dari tindakan, dalam hal ini hukuman ${ }^{29}$. Apabila akibat dari hukuman itu baik bagi kepentingan banyak orang, maka hukuman juga dapat diterima. Karena hukuman ketika dipandang bermanfaat untuk mencegah dipandang bermanfaat untuk mencegah terjadinya pelanggaran terhadap hak warga negara, dan dengan demikian mengontrol kejahatan, maka dibenarkan karena menciptakan keamanaan dan kebahagiaan publik ${ }^{30}$.

Hukuman penting untuk meningkatkan perlindungan terhadap hak warga negara. Singkatnya, hukuman dari sudut utilititarianisme dibenarkan semata-mata karena membawa efek sosial positif bagi hak warga. Akibat baik dari hukuman harus selalu menjadi pertimbangan dalam menjatuhkan hukuman karena hukuman apapun bentuknya dan seberapa pun beratnya akan selalu merupakan penderitaan bagi terhukum. Hukuman mencabut secara paksa hal-hal yang dipandang bernilai oleh terhukum. Hukuman membuat terhukum kehilangan kebebasan; ia ditempatkan dalam isolasi. Penderitaan adalah sesuatu yang buruk, dan karenanya perlu dipertanggungjawabkan meskipun tertuduh dipandang pantas menanggungnya. Bagi utilitarianisme,

28 Ibid, Hlm. 118

29 Ujan Andreata, Membangun Hukum, Membela Keadilan, Filsafat Hukum, (Yogyakarta : Kanisius, 2009), Hlm. 107

$30 \mathrm{Ibid}, \mathrm{Hlm} .107$ 
mencegah penderitaan atau kerugian yang lebih besar. Penderitaan karena hukuman perlu untuk mencegah kejahatan lebih lanjut dan sekaligus menjamin kebaikan umum . Dengan demikian, dari sudut utilititarianisme terdapat dua fungsi hukuman : pertama hukuman membuat si terhukum atau orang lain menjadi tidak mampu untuk melakukan kejahatan. Kedua fungsi rehabilitasi ${ }^{31}$.

Penerapan Omnibus law sebagai solusi regulasi investasi memiliki tujuan yang fundamental diatur dalam UUD 1945. Kebermanfaatan perlu diraih karena jika terjadi kebermanfaatan akan ada suatu manfaat dari kebijakan terutama dalam mewujudkan kemakmuran rakyat. Ketika omnibus law dibuat dan diundangkan maka tentu akan mempermudah izin investasi. Mudahnya izin akan menarik perhatian investor karena dipermudan untuk melakukan penanam modal. Dari penanaman modal tersebut akan berimplikasi pada peningkatan perekonimian yang kemudan menjamin terwujudnya kebermanfaatan hukum atas beralakunya omnibus law kepada masyarakat.

\section{Keadilan Hukum}

Tujuan hukum berikutnya adalah keadilan, menurut Radbruch bahwa keadilan sudah cukup jika kasus yang sama diperlakukan sama ${ }^{32}$. Sedangkan menurut Sebagaimana dikatakan oleh Tegus Prasetyo bahwa: "Orang dapat saja mengatakan tujuan hukum adalah keadilan saja, dan itu berarti di dalam keadilan itu sudah pasti ada pula kepastian dan selalu saja diperoleh manfaat" 33 . Geny adalah salah satu ahli yang juga mendukung bahwa hukum bertujuan merealisir atau mewujudkan keadilan ${ }^{34}$. Ia berpendapat sebagaimana dikutip oleh Van Apeldoorn demikian:

"Geny mengajarkan, bahwa tujuan hukum ialah sematamata keadilan, akan tetapi merasa terpaksa juga memasukkan kepentingan daya guna dan kemanfaatan

31 Ibid, Hlm. 108

32 O. Notohamidjojo, Op.Cit, Hlm. 35

33 Teguh Prasetyo, Keadilan Bermartabat Perspektif Teori Hukum, (Nusa Media : Bandung, 2015), Hlm. 77

34 Mertokusumo Sudikno, Mengenal Hukum....,Op.Cit, Hlm. 77 
Omnibus Law Sebagai Reformasi Hukum Investasi di Indonesia Berdasarkan Asas Hirarki Peraturan Perundang-Undangan

sebagai sesuatu unsur dari pengertian keadilan: le juste contient dans ses flancs l'utile" 35 .

Tujuan hukum satu-satunya adalah tidak lain daripada mewujudkan keadilan. Bahwa pendapat yang secara panjang lebar menguraikan bahwa hukum bertujuan untuk tiga tujuan yaitu keadilan kepastian dan kemanfaatan, rasionalisasi yang tepat bahwa kalau keadilan yang dikejar maka kepastian dan kemanfaatan secara otomatis akan terwujud, karena baik kemanfaatan dan kepastian adalah bagian dari keadilan itu sendiri. Jadi pada dasarnya, kepastian dan manfaat tidak ditempatkan secara palarel dengan keadilan sebagai tujuan hukum, tetapi sebagai sarana untuk mencapai keadilan itu sendiri ${ }^{36}$.

Maka dari itu tujuan hukum pastilah keadilan. Pembukaan keran investasi yang mudah bukan atas dasar komersial. Ada beberapa pihak yang perlu dijaga sehingga kebijakan ini tetap berjalan dengan baik. Terutama antara negara dan Investor bahwa kebijakan investasi harus saling menguntungkan. Tanpa ada kepentingan-kepentingan salah satu antara negara maupun investor. Sehingga dampaknya akan mengarah kepada masyarakat.

Permasalahan negara hukum tentu banyak aspek yang perlu diperhatikan. Karena sejatinya aturan hukum yang dimanifestasikan kedalam kebijakan formal, tujuan utamanya adalah keadilan. Saat ini banyak sekali permasalahanpermasalahan jika dilihat dari sudut pandang keadilan tentu memiliki nilai yang kontradiktif. Ketika kebijakan negara yang bukan atas kepentingan rakyat, maka dampaknya juga akan terasa kepada rakyat terutama dampak buruk. Sehingga Indonesia sebagai negara hukum harus menjalankan supremasi hukum dalam bidang aspek ekonomi. Landasannya adalah bahwa negara Indonesia selain negara hukum juga mengemban tugas sebagai negara kesejahteraan. Artinya negara Indonesia juga memiliki tanggung jawab untuk mensejahterakan rakyatnya. Salah satunya adalah dengan

35 Van Apeldorn, Pengantar Ilmu Hukum, Op.Cit, Hlm. 16

36 Op.Cit, Hlm. 18 


\section{Kesimpulan}

menjalankan roda perekonomian yang baik. Tentu mewujudkan sektor peningkatan perekonimian memiliki banyak strategi. Salah satunya membuka keran investasi agar terdapat penaman modal sebagai pembangunan negara di Indonesia. Maka dari itu omnibus law menjadi solusi dalam permasalahan investasi karena regulasi ini akan menjadi senjata pamungkas penarik minal investor dengan perizinan yang lebih mudah dan sederhana.

Kesimpulan yang dapat diambil dalam penulisan ini terdiri dari 2 (dua) kesimpulan yaitu :

1. Berdasarkan perspektif peraturan perundang-undangan berlakunya Omnibus law dalam aspek ekonomi akan terdapat asas lex superiori derograt legi priori. Yaitu omnibus law menjadi undang-undang dan jika peraturan dibawahnya tidak sejalan dengan omnibus law ini maka akan dikesampingkan (tidak diterapkan) karena omnibus law memiliki kedudukan lebih tinggi. Kemudian juga berlaku asas lex post teriori derogra legi apriori. Yaitu omnibus law akan menjadi aturan baru dalam sektor investasi perekonomian. Jika ada undang-undang sebelumnya tidak sesuai dengan amanat omnibus law ini makan undang-undang tersebut tidak digunakan karena bersifat aturan yang lama. Akan tetapi perlu ada penegasan didalam ketentun peralihan maupun penutup dalam Omnibus law.

2. Urgensi omnibus law sebagai solusi regulasi investasi di Indonesia adalah karena Indonesia merupakan negara hukum yang memiliki peran negara kesejahteraan. Dengan dibentukan dan diundangnyanya omnibus law akan mempermudah investasi bagi pihak investor yang tentunya akan berdampak pada peningkatan keekonomian sebagai kemakmuran rakyat. Omnibus law sebagai aturan hukum akan mewujudkan aturan hukum dalam aspek ekonomi sebagai bentuk kepastian hukum, kebermanfaatan dan keadilan.

\section{Daftar Pustaka}

\section{Buku :}


Omnibus Law Sebagai Reformasi Hukum Investasi di Indonesia Berdasarkan Asas Hirarki Peraturan Perundang-Undangan

Abdulkadir, Muhammad, Hukum dan Penelitian Hukum Cet. 1, (Bandung : PT. Citra Aditya Bakti), 2004

Bagir Manan, Pertumbuhan dan Perkembangan Konstitusi Suatu Negara, (Bandung : Mandar

Gianfranco Poggi, The Development Of The Modern State "Sosiological Introduction, (California : Stanford Uiversity press), 1992

Jimly Asshiddiqie, Hukum Tata Negara dan Pilar-Pilar Demokrasi, (Jakarta : Konstitusi Press), 2004

M. Yamin, Naskah Persiapan UU 1945 : Risalah Sidang BPUPKI/ PPKI, (Jakarta : Sekretariat Jendral RI), 1959

Mahendra Kurniawan, Dkk, Pedoman Naskah Akademik PERDA Partisipatif, (Yogyakarta : Kreasi Total Media), 2007

Marzuki, Peter Mahmud, Penelitian Hukum, Cet. 2, (Jakarta : Kencana), 2008

Mertokusumo Sudikno \& Pilto, Bab-Bab Penemuan Hukum, (Citra Aditya Bakti : Bandung) Mengenal Hukum : Sebuah Pengantar, (Liberty : Yogyakarta, 2008)

Modiharjo, Darji Dar \& Shidarta Arif, Pokok-Pokok Filsafat Hukum, (Jakarta : Gramedia, 2006),

O. Notohamidjojo, Soal-Soal Pokok Filsafat Hukum, (Griya Media : Salatiga, 2011)

Oemar Seno Adji, Prasarana Dalam Indonesia Negara Hukum, (Jakarta : Simposium UI), 1966,

Plato, The Laws, Penguin Classics, Edisi 1986, translate by Trevor J. Saunders.

Priyanto, Kuat Puji, Pengantar Ilmu Hukum (Kesenian Hukum dan Penemuan Hukum dalam Konteks Hukum Nasional), (Yogyakarta : Kanwa Publisher, 2011)

Rasjidi Lili \& Rasjidi, Ira Thania, Pengantar Filsafat Hukum, (Bandung : Mandar Maju, 2002)

Soekanto Soerjono, Penelitian Hukum Normatif : Suatu Tinjauan Singkat, (Jakarta : Raja Grafindo), 2001

Soemardi, Teori Hukum dan Negara: Dasar-Dasar Ilmu Hukum Normatif Sebagai Ilmu Hukum Deskriptid - empirik, (Bandung : Bee Media Indonesia,

Sugiarto, Umar Said, Pengantar Hukum Indonesia, (Jakarta : Sinar Grafika), 2013 
Swasosno. Sri Edi, Tentang Demokrasi Ekonomi, (Jakarta : Bappenas), 2008

Teguh Prasetyo, Keadilan Bermartabat Perspektif Teori Hukum, (Nusa Media : Bandung, 2015),

Ujan Andreata, Membangun Hukum, Membela Keadilan, Filsafat Hukum, (Yogyakarta : Kanisius, 2009

Utrecht, Pengantar Hukum Administrasi Negara Indonesia, (Jakarta : Ikhtiar), 1962

Van Apeldorn, Pengantar Ilmu Hukum (Cet. 32), (Pradya Paramitha : Jakarta, 2000)

Wignjosoebroto Soetandyo, Hukum : Paradigma. Metode dan Dinamikanya, (Jakarta : Elsam \& Huma)

Jurnal :

Bisariyadi, Pergulatan Paham Negara Kesejahteraan (Welfare State) dan Negara Regulasi (Regulatory State) dalam Perkara Konstitusional, Jurnal Hukum Ius Quia Iustum, Vol. 23, No. 4 , Bulan Oktober 2016

Busroh, Firman Freaddy, Konseptualisasi Omnibus Law Dalam Menyelesaikan Permasalahan Regulasi Pertanahan, Jurnal Arena Hukum, Vol. 10, No. 2, Bulan Agustus Tahun 2017

Oman Sukmana, Konsep dan Desain Negara Kesejahteraan (Welfare State), Jurnal Sospol, Vol. 2 No. 1 (Juli-Desember 2016)

Internet :

D. Soekarno, Amandemen Terhadap UUD 1945, Suara Pembaharuan : http/www. Suarapembaharuan.com, diakses pada tanggal 11 November Tahun 2019 Pukul 21.55 WIB

Jimly Asshidiqie, Gagasan Negara Hukum Indonesia : https://pngunungsitoli.go.id/assets/image/files/Konsep_Negara_ Hukum_Indonesia.pdf, diakses pada tanggal 12 November 2019 Pukul 21.13 Wib.

Kompas, Apa itu Omnibus Law, Yang Disinggung Jokowi dalam Pidatonya? https://www.kompas.com/tren/read/2019/10/22/0706 00665/apa-itu-omnibus-law-yang-disinggung-jokowidalam-pidatonya-?page=all, diakses pada tanggal 11 November 2019 Pukul 21.59 Wib 
Omnibus Law Sebagai Reformasi Hukum Investasi di Indonesia Berdasarkan Asas Hirarki Peraturan Perundang-Undangan 